\title{
ADVANCED DESIGN OF JOINTS WITH STEEL ELEMENTS IN TIMBER STRUCTURES
}

\author{
K. Vopatová ${ }^{*}$, B. Židlický ${ }^{* *}$, M. Kuř́íková ${ }^{* * *}$, K. Cábová ${ }^{* * * *}$
}

\begin{abstract}
Presented paper is focused on the design of timber joints with inserted steel sheet. Topicality of the problematic is presented together with a description of joints with the inner steel plate design and failure modes. The design resistance calculation is described in detail. The numerical model created in finite element software Abaqus is described. The analytical model was considered according to code EN 1995-1-1 (2006). The aim of this research is to show and compare numerical results of the timber joint with the current codified procedure provided by EN 1995-1-1 (2006), the general method and some proposals developed by other researchers recently. Furthermore, research results provide backgroung for the numerical software creation dealing with steel-timber joints. The numerical model validation made based on the analytical model is presented. Experimental programme is presented and its data serve for numerical model validation, as well.
\end{abstract}

Keywords: Timber; Timber structure; Joint; Steel plate; Experiment; Numerical model.

\section{Introduction}

Timber load-bearing structures consist of members, elements and joints. Almost an endless number of solutions exist for the timber structural joints design. The joints ensure the integrity of the structure and transfer the internal forces, caused by the acting load from one connected element to the other. The joint should not be designed as a weak point of the structure because its failure usually leads to a failure of the whole system. However, behaviour of joints is influenced by a number of variables, such as material properties, geometry and element interaction, etc.

This paper is focused on the timber joints with inserted steel sheet. This type of joint exhibits significantly higher load-bearing capacity compared to the classic timber joints. It is suitable for the design of highly stressed timber structures, for example large-span structures.

\section{Experimental study}

For the experimental study a set of specimens was proposed. The test specimens are designed for the closest approximation of a real-world designing joints. These are timber joints with inserted steel plate connected with bolts. Only one specimen is presented herein the others will be described at the conference.

The timber element is made of sturdy timber of C24 strength class. The gap, where the steel sheet will be situated, is designed according to EN 1995-1-1 (2006) code requirements. The depth of the gap will be

\footnotetext{
* Ing. Kristýna Vopatová: Faculty of Civil Engineering, Czech Technical University in Prague, Thákurova 7; 166 29, Prague 6; CZ, kristyna.vopatova@fsv.cvut.cz

** Ing. Břetislav Židlicky: Faculty of Civil Engineering, Czech Technical University in Prague, Thákurova 7; 166 29, Prague 6; CZ，bretislav.zidlicky@fsv.cvut.cz

*** Ing. Marta Kuř́ková, Ph.D.: Faculty of Civil Engineering, Czech Technical University in Prague, Thákurova 7; 166 29, Prague 6; CZ, marta.kurikova@fsv.cvut.cz

**** Ing. Kamila Cábová, Ph.D.: Faculty of Civil Engineering, Czech Technical University in Prague, Thákurova 7; 166 29, Prague 6; CZ, kamila.cabova@ffsv.cvut.cz
} 
$5 \mathrm{~mm}$ deeper than the dived length of the steel plate, which varies depending on the diameter of the fastener and required pitch. With regard to commonly used joints steel S235JR has been proposed. Classical M16 bolts (with $16 \mathrm{~mm}$ of diameter) will be used as a fastening elements. Experimental setup is shown by Figure 1.
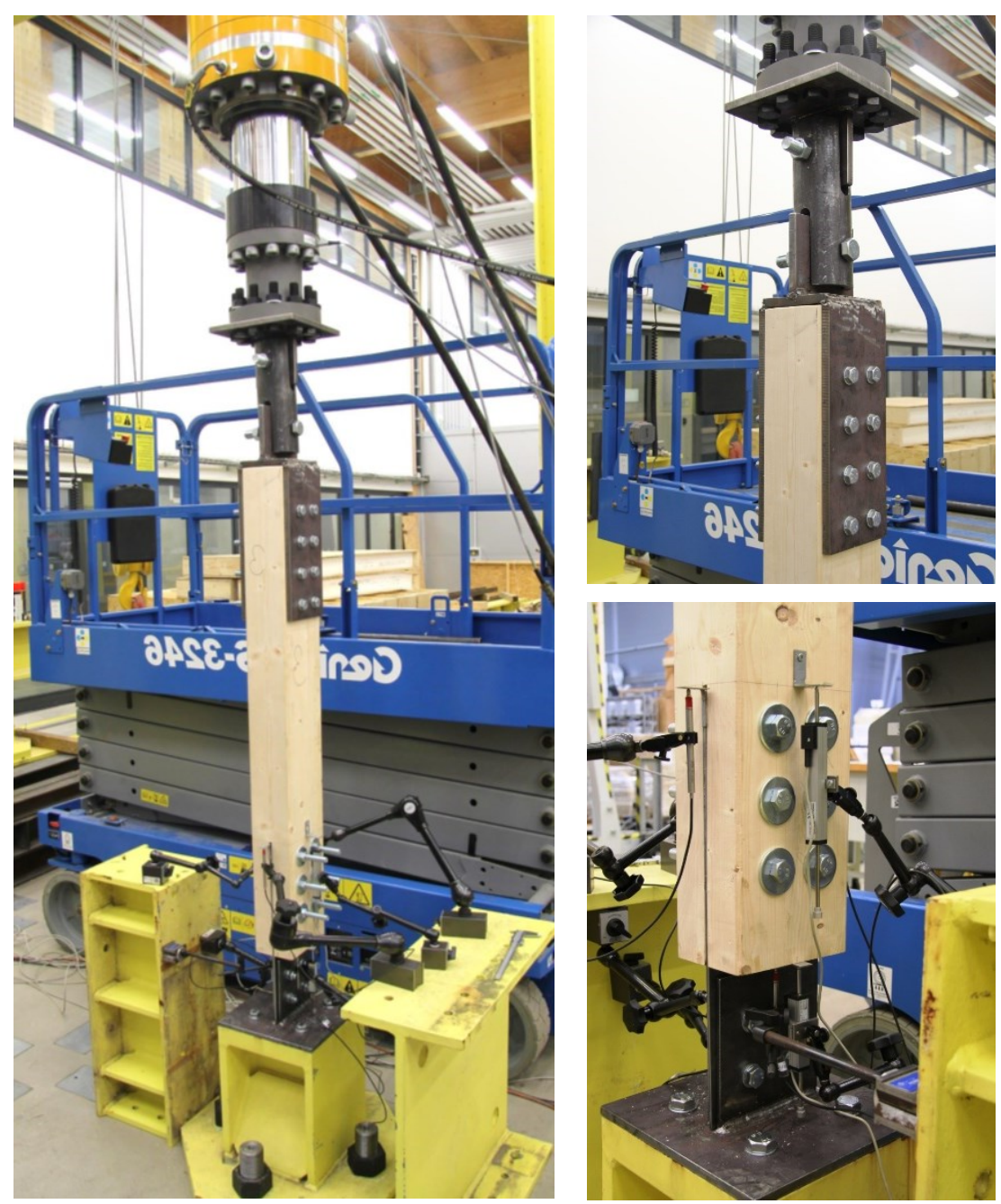

Fig. 1: Experimental setup.

\section{Numerical model}

Numerical model was created in finite element software Abaqus in order to obtain the real behaviour of steel-timber joints. A solid element 3D model using GMNIA (geometrically and materially non-linear analysis with the imperfection) was used. The assembly of the whole joint is provided by Figure 2 . C3D8R was used for mesh which compromising result accuracy and calculation duration.

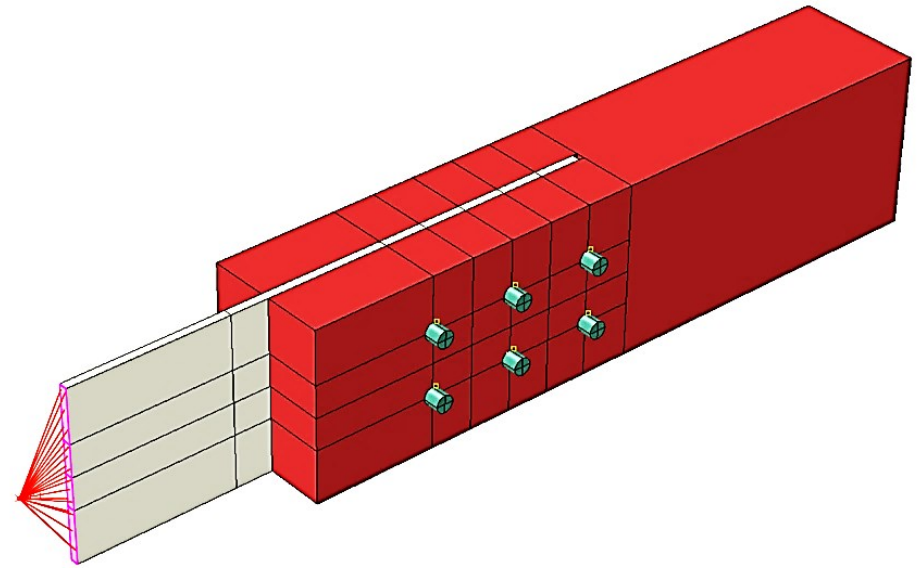

Fig. 2: Numerical model assembly. 


\subsection{Material properties}

The isotropic plastic material was used for the steel elements of the joint representation. The timber has been modelled preliminarily as an orthotropic elastic material. Introduction of the timber plasticity is a subject of further work. The linear material timber model was defined by nine independent elastic constants: Young's elastic moduli $E_{L}, E_{R}, E_{T}$; shear moduli $G_{L R}, G_{L T}, G_{R T}$ and Poisson's coefficients $v_{L R}$, $v_{L T}, v_{R T}$ regarding the appropriate axis. Due to the fact that material properties of timer are depended on the axis direction a local coordinate system with associated with stress matrix constants and then assigned to the timber elements of the joint. The main nine parameters describing material properties of timber were obtained from the literature EN 338 (2016) and they are given by Table 1 (index L means longitudinal, $\mathrm{R}$ means radial and $\mathrm{T}$ means tangential direction). A density of timber was considered as $430 \mathrm{~kg} / \mathrm{m}^{3}$.

Tab. 1: Timber material properties.

\begin{tabular}{ccc}
\hline $\begin{array}{c}\text { Young modulus } \\
{[\mathrm{MPa}]}\end{array}$ & $\begin{array}{c}\text { Shear modulus } \\
{[\mathrm{MPa}]}\end{array}$ & $\begin{array}{c}\text { Poisson's coefficient } \\
{[-]}\end{array}$ \\
\hline$E_{\mathrm{L}}=11000$ & $G_{\mathrm{LR}}=690$ & $v_{\mathrm{LR}}=0.04$ \\
\hline$E_{\mathrm{R}}=370$ & $G_{\mathrm{TL}}=690$ & $v_{\mathrm{TL}}=0.04$ \\
\hline$E_{\mathrm{T}}=370$ & $G_{\mathrm{RT}}=50$ & $v_{\mathrm{RT}}=0.4$ \\
\hline
\end{tabular}

For the steel elements Poisson's coefficient and Young modulus of elasticity were considered as $v_{\text {Steel }}=0,3$ and $E_{\text {Steel }}=210000 \mathrm{MPa}$ values, respectively. For the initial numerical model, material behaviour of the steel plate was adopted from the literature where the tensile tests of the same steel grade were conducted. However, tensile test conduction is planned even in this research in order to obtain the real material properties. Material model of bolts was considered as in Gödrich (2017). Density of both steel plate and bolts is considered as a $7850 \mathrm{~kg} / \mathrm{m}^{3}$. As could be seen, the SI units were considered.

\subsection{Applied load and boundary conditions}

The loading force was introduced through the reference point situated out of the model assembly but in its centroid, however. Due to the fact that loading force acts only on the steel plate the reference point was rigidly connected with the outer steel plate surface, which ensured the stress distribution in the whole cross-section. It was necessary to use two sets of boundary conditions. First, expected rigid boundary condition situated on the end of the timber element (opposite site than reference point situation). Then, it was necessary to support each joint element in the initial step, in order to define orientation in the coordinate system for calculation beginning.

\subsection{Contact definition}

The contact bonds were defined between the bolts and the timber element as well as between the bolts and the steel sheet. The parameters of the mutual behaviour of the individual joint elements were determined. Surface to surface contact was considered with combination of normal (hard contact) and tangential (friction coefficient equal to 0.2 ) contact behaviour.

Numerical model results are given by Figure 3. Both analytical and numerical models were loaded by tensile force with ultimate strength considered as a nominal fiber strength, according to EN 1995-11(2006). Validation is given by Table 2, where comparison of numerical and analytical model results is made with $\sigma_{\text {II }}$ being the stress in the fiber direction.

Tab. 2: Model comparison at ultimate stress level.

\begin{tabular}{cccc}
\hline Model & $\begin{array}{c}\boldsymbol{\sigma}_{\text {II }} \\
{[\mathbf{M P a}]}\end{array}$ & $\begin{array}{c}\text { Force } \\
{[\mathbf{k N}]}\end{array}$ & $\begin{array}{c}\text { Deformation } \\
{[\mathbf{m m}]}\end{array}$ \\
\hline Analytical & 14.00 & 138 & 0.814 \\
\hline Numerical & 14.00 & 145 & 0.814 \\
\hline
\end{tabular}


As could be seen in Table 2 the numerical model is in a good agreement with the analytical model. However, it should be noted that the failure mode is not implemented in the numerical model, yet. To implement failure mode for the steel-timber joint is necessary to use Fortran subroutine which allows to consider the user-defined material model. For instead, geometry, boundary conditions, mechanical and moisture properties, load, and model computational network and failure mode can be defined for the elements. For future improvements of the numeric model, Intel Visual Fortran 12.0 and Visual Studio 2010 will be needed to define the real material properties of a timber considering failure. After implementation of subroutines, the numerical model will be validated based on the conducted experiments described above.

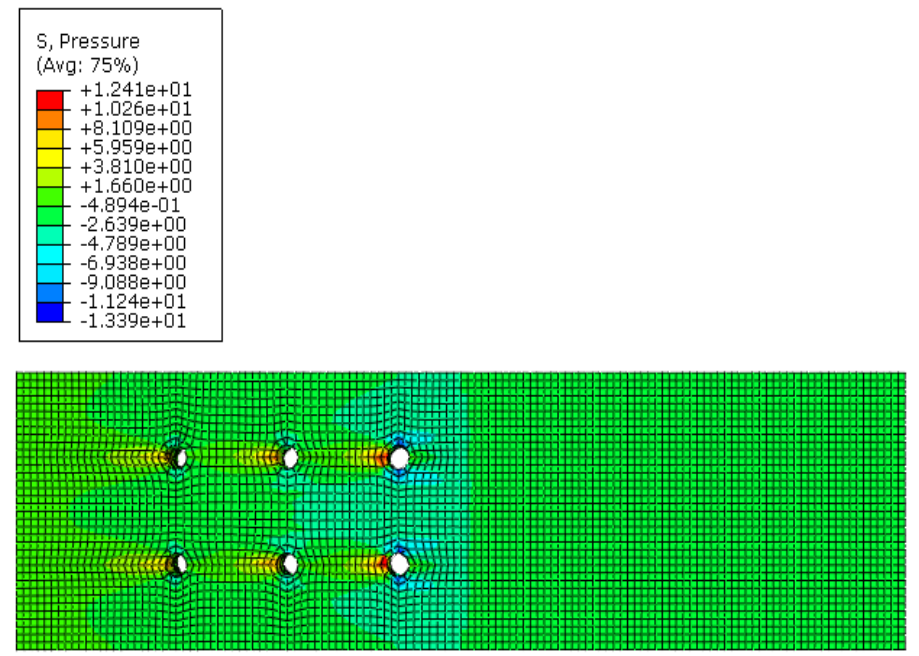

Fig. 3: The stress results of the numerical model simulation.

\section{Conclusions}

The main objective of this paper is to study behaviour of timber joints with inserted steel sheets. The joints exhibit a relatively high load-bearing capacity and are suitable for design and for places with increased strength. Both experimental and numerical study was presented. Furthermore, numerical model was described in detail, its validation based on the analytical model was shown and some coming improvements were presented together with following works which will serve as a background for the numerical software creation dealing with steel-timber joints.

\section{Acknowledgement}

This work was supported by the grant of the Technical agency ČR TJ01000315 which is gratefully acknowledged.

\section{References}

EN 1995-1-1. (2006) Eurocode 5: Design of timber structures - Part 1-1: General - Common rules and rules for buildings, CEN, Brussel.

GÖDRICH, Lukáš. (2017) Diskrétní modelování čelní desky. Ph.D Thesis. Czech technical university in Prague, Czech Republic (in Czech)

JOHANSEN, K. (1949) Theory of timber connections. International association for bridge and structural engineering (IABSE). Pub. 9; 249-622.

POŽGAJ, Alexander, Dušan CHOVANEC, Stanislav KURJATKO a Marián BABIAK. (1997) Štruktúra a vlastnosti dreva 2. Bratislava: Príroda. ISBN 80-07-00960-4 (in Slovak).

STRAKA, Bohumil a Milan ŠMAK. (2007) Halové stavby s dřevěnými obloukovými, vazníkovými a rámovými nosnými dílci. Časopis stavitelství.

PĚNČÍK, Jan. (2014) Modelování dřeva pomocí ortotropního materiálového modelu s kritérii porušení. Stavební obzor (2), 7 (in Czech).

Abaqus Analysis User's Guide. (2014) Ver. 6.14 Documentation. Johnston: Dassault Systèmes Simulia Corporation.

EN 338. (2016) Structural timber - strength classes, 2, CEN, Brussel.

EN 13183-2. (2002) Moisture content of a piece of sawn timber - estimation by electrical resistance method, CEN, Brussel. 